\title{
ADDRESSING THEMES RELATED TO STOMATHERAPY IN UNDERGRADUATE NURSING EDUCATION: DOCUMENT ANALYSIS
}

\author{
Francielle Paula de Freitas Morais ${ }^{1, *}\left(\mathbb{D}\right.$, Paulo Henrique Fernandes dos Santos ${ }^{2}$ (D), \\ Fernanda Letícia Frates Cauduro² (B)
}

\begin{abstract}
Objective: discuss the approach of themes related to stomatherapy in Pedagogical Projects (PP) and syllabuses of undergraduate nursing courses from public institutions of higher education (PIHE) in the Brazilian Midwest. Method: documentary research, exploratory, with a qualitative approach, developed from March to June 2020. The nursing courses were located through access to the Ministry of Education's online portal (e-MEC) and the PP and the subject syllabuss were accessed, when available. Results: The sample consisted of 17 graduation nursing courses. Themes related to stomatherapy are present in mandatory, elective or extension activities. It was identified a predominance of wound content in mandatory subjects, and the themes ostomy and incontinence are offered mainly in elective subjects or extension activities. Conclusion: the research aims to offer the PIHE subsidies for reflection and curriculum evaluation in the dissemination of topics related to stomatherapy in higher education in nursing
\end{abstract}

DESCRIPTORS: Ostomy. Nursing. Teaching. Nursing education. Stoma therapy.

\section{ABORDAGEM DE TEMAS CORRELATOS A ESTOMATERAPIA NO ENSINO DE GRADUAÇÃO EM ENFERMAGEM: ANÁLISE DOCUMENTAL}

\section{RESUMO}

\begin{abstract}
Objetivo: discutir a abordagem de temas correlatos à estomaterapia nos Projetos Pedagógicos (PP) e ementas de cursos de graduação de enfermagem de instituições públicas de ensino superior (IPES) do centro-oeste brasileiro. Método: pesquisa documental, exploratória, de abordagem qualitativa, desenvolvida no período de março a junho de 2020. Os cursos de enfermagem foram localizados por meio de acesso ao portal on-line do Ministério da Educação (e-MEC) e acessados os PP e ementas das disciplinas, quando disponíveis. Resultados: compuseram a amostra 17 cursos de graduação em enfermagem. Temas correlatos à estomaterapia estão presentes em disciplinas obrigatórias, optativas ou atividades extensionistas. Identificou-se predominância do conteúdo de feridas em disciplinas obrigatórias, e os temas estomias e incontinências são ofertados principalmente em disciplinas optativas ou atividades extensionistas. Conclusão: a pesquisa almeja ofertar às IPES subsídios para reflexão e avaliação curricular na difusão de temas correlatos à estomaterapia na formação superior em enfermagem.
\end{abstract}

DESCRITORES: Estomia. Enfermagem. Ensino. Educação em enfermagem. Estomaterapia.

1. Escola Superior de Ciências da Saúde do Distrito Federal - Secretaria de Saúde do Distrito Federal - Brasília (DF), Brazil. 2. Universidade de Brasília - Faculdade de Ciências da Saúde - Departamento de Enfermagem - Brasília (DF), Brazil.

*Correspondence author: franpaula.freitas@gmail.com

Section Editor: Isabel Cristina R V Santos

Received: Mar. 2021,17 | Accepted: Set. 2021, 21

How to cite: Morais FPF; Santos PHF; Cauduro FLF. Addressing themes related to stomatherapy in undergraduate nursing education: document analysis. ESTIMA, Braz. J. Enterostomal Ther., 2021, 19: e2421. https://doi.org/10.30886/estima.v19.1028_IN 


\title{
ENFOQUE DE TEMAS RELACIONADOS A LA ESTOMATERAPIA EN LA ENSEÑANZA DE GRADUACIÓN EN ENFERMERÍA: ANÁLISIS DOCUMENTAL
}

\begin{abstract}
RESUMEN
Objetivo: discutir el enfoque de temas relacionados a la estomaterapia en los Proyectos Pedagógicos (PP) y descripciones de cursos de graduación de enfermería de instituciones públicas de enseñanza superior (IPES) del centro-oeste brasileño. Método: investigación documental, exploratoria, de enfoque cualitativo, desarrollada en el período de marzo a junio del 2020. Los cursos de enfermería fueron localizados por medio de acceso al portal online del Ministerio de la Educación (e-MEC) y accedidos los PP y descripciones de las asignaturas, cuando estén disponibles. Resultados: compusieron la muestra 17 cursos de graduación en enfermería. Temas relacionados a la estomaterapia están presentes en asignaturas obligatorias, optativas o actividades extensionistas. Se identificó predominancia del contenido de heridas en asignaturas obligatorias, y los temas estomías e incontinencias son ofertados principalmente en asignaturas optativas o actividades extensionistas. Conclusión: la investigación desea ofertar a las IPES subsidios para la reflexión y evaluación curricular en la difusión de temas relacionados a la estomaterapia en la formación superior en enfermería.
\end{abstract}

DESCRIPTORES: Estomía. Enfermería. Enseñanza. Educación en enfermería. Estomaterapia.

\section{INTRODUCTION}

During university education, nursing students are faced with a wide range of disciplines and contents. The National Curriculum Guidelines (Diretrizes Curriculares Nacionais) for undergraduate nursing courses, they guide towards generalist training. It is expected that the future professional is qualified to act and intervene in health promotion, prevention, protection and rehabilitation actions, providing comprehensive care to individuals, families and communities facing the multiplicity of health-disease problems and situations ${ }^{1}$.

At the three levels of health care, nurses will be able to attend to individuals with health needs that cover the field of stomatherapy, a nursing specialty that aims to care for individuals with ostomies, acute and chronic wounds, fistulas, tubes, catheters, drains, anal and urinary incontinence ${ }^{2}$.

As a specialty, stomatherapy emerged in the late 1950s in the United States, but it was only in 1980 that it was included as a specialty for nursing by the World Council of Enterostomal Therapists (WCET). This entity aims to ensure that specialized nursing care is available worldwide for people in need of ostomy care, wounds or continence ${ }^{3}$. In Brazil, the milestone of stomatherapy occurred with the opening of the first specialization course offered by the School of Nursing at Universidade de São Paulo in $1990^{2}$.

The demand for this specialty is growing and a study conducted with stomal therapist nurses who graduated from a specialization course in Brazil revealed that, in the studied population, 70\% worked in the area, predominantly for the care of ostomies and wounds ${ }^{4}$. Although the data reveal a high insertion of these professionals in the labor market, it is urgent to point out that nursing care for patients with demands in this field is also offered by generalist nurses.

In this respect, nurses who are not stomal therapists, but who care for individuals with such morbidities, many of which are highly complex, must be prepared to provide the minimum care and, when appropriate, identify the need for referral to a specialized service ${ }^{5}$. It is considered, therefore, that during nursing graduation, it is essential to offer content involving stomatherapy, so that the graduate can develop minimum skills to care for these patients.

Through the observation of researchers during the performance of didactic-pedagogical activities in a public institution of higher education (PIHE) in the Brazilian Midwest, and the perception of weaknesses in the knowledge of nursing students about contents related to wounds, ostomies and incontinence, he questioned how educational institutions have contemplated content within the scope of stomatherapy in nursing education. 
This research aimed to discuss the approach of themes related to stomatherapy in Pedagogical Projects (PP) and syllabuses of undergraduate nursing courses at PIHE in the Brazilian Midwest. It is expected that the data produced will contribute to nursing education at a higher level by causing teachers to reflect on the relevance of including, or expanding, content associated with stomatherapy to generate a positive impact on care, as well as providing elements that support the development of curriculum-based research.

\section{METHOD}

This is a documentary, exploratory research, with a qualitative approach, developed from March to June 2020, whose research question was "How do we approach topics related to stomatherapy in undergraduate nursing courses at PIHE in the mid- west of Brazil?". To obtain data, the steps described by Rodrigues were followed ${ }^{6}$ identification, selection and eligibility. The identification stage was carried out from the access to the higher education institutions portal of the Ministry of Education (e-MEC). In the second stage, of selection, the undergraduate courses in on-site nursing from PIHE, bachelor's and licentiate's qualifications were identified. Eligibility occurred by accessing the courses' online pages and verifying the availability of the PP and the disciplines' syllabus, including the institutions that had such information.

When exploring the web pages, indications of the development, in some institutions, of outreach activities focused on stomatherapy were noted. In this way, this information was also compiled.

All PP and syllabuses were read in full. To identify contents related to stomatherapy, the following terms were searched: "cuidados com a pele"(skin care), "lesão de pele"(skin lesion), "lesão por pressão"(pressure injury), "feridas"(wounds), "escaras" (bedsores), "estoma”(stoma), "ostoma”(ostomy), “estomias”(ostomies), “ostomias”, "estomizados”, "ostomizados” (ostomized), “incontinência(s)" (incontinence/s), "fístulas”, "drenos” (drains) , "cateteres” (catheter), "tubos” (tubes) e "estomaterapia” (stomatheraphy). It is noteworthy that all derivations and prefixes associated with the term "ostomies" were considered. Information that contained the term "skin" contained in the basic subjects of the curriculum (for example, anatomy and physiology) was excluded. The same criterion was applied to terms identified in the description and specification of inputs for skills training in nursing laboratories.

The tabulation of information was performed in an $\operatorname{Excel}^{\circledR}$ spreadsheet with the registration of the elements: State, PIHE, course hours, year of PP, total number of subjects per semester, indication of the semester of the course and extension activity. In identifying the PIHE, codes were applied according to the State of the Federation and consecutive numbers for organizational purposes. For interpretation, thematic-category content analysis was used, based on the assumptions of Bardin's content analysis, namely: exhaustive reading of $\mathrm{PP}$ and syllabuses, construction of provisional hypotheses about the object of study, determination of registration units, definition of units of meaning and quantification of themes, grouping of themes based on theoretical criteria and presentation of results ${ }^{7}$.

As this data is in the public domain, the project was not submitted to the Research Ethics Committee, following the guidelines of the National Health Council (Conselho Nacional da Saúde) no 510/2016.

\section{RESULTS}

In the e-MEC system, 19 PIHE in midwestern Brazil were identified, however 2 institutions did not meet the preestablished inclusion criteria. Thus, the final analysis was performed on the documents of 17 undergraduate nursing courses, distributed in the states of Goiás ( $\mathrm{n}=05)$, Mato Grosso ( $\mathrm{n}=05)$, Mato Grosso do Sul ( $\mathrm{n}=04)$ and the Distrito Federal ( $\mathrm{n}=03$ ).

Regarding the approach to themes related to stomatherapy, the corpus submitted for analysis emerged from mandatory and elective disciplines and extension activities.

After floating and intuitive reading of the data and definition of provisional hypotheses ${ }^{7}$, registration units, themes and categories were organized. In this aspect, it was possible to establish the approach of themes related to stomatherapy under three thematic categories: Approach in mandatory subjects; Approach in elective courses; Approach in outreach activities. 


\section{Category 1: Approach to themes related to stomatherapy in compulsory subjects}

Among the PP and analyzed syllabuses, in 16, at least 1 term was found. These are included in the description of syllabuses, contents, teaching topics or bibliographical references, which are mandatory or complementary. Thus, in this category, two subcategories were defined: Stomatherapy in teaching syllabuses, contents and topics e Bibliography for teaching topics related to stomatherapy.

\section{Stomatherapy in teaching syllabuses, contents and topics}

The terms that were most repeated in this subcategory were "feridas" (wounds), "curativos" (dressings) and "integridade da pele" (skin integrity); in only one syllabus was found the term "cateterismo" (catheterization), "drenos" (drains)and the suffix "ostomy". It was found that undergraduate nursing students approach the topic between the third and sixth semester of the course, in subjects focused on knowledge and skills training (nursing fundamentals, semiotechnics/semiology and care process). The presentation of the results is shown in Table 1.

Table 1. Distribution of data from public higher education institutions according to semester, discipline, syllabus, content and teaching topic. Brasília (DF) - 2020.

\begin{tabular}{|c|c|c|c|}
\hline PIHE & Semester & Discipline & Syllabus/ Content/Teaching topic \\
\hline Nur/DF1 & $\begin{array}{l}\text { 4th } \\
\text { semester }\end{array}$ & $\begin{array}{l}\text { Semiology and } \\
\text { Semiotechnics }\end{array}$ & $\begin{array}{l}\text { Nursing care used in the integumentary deficit: care for wounds; beware } \\
\text { of drains. Nursing care used in nutritional and electrolyte deficit: gastric } \\
\text { catheterization; duodenal catheterization; intermittent and delayed vesical } \\
\text { catheterization. Nursing care used in ventilatory deficit: tracheostomy. }\end{array}$ \\
\hline Nur/GO1 & $\begin{array}{l}\text { 6th } \\
\text { semester }\end{array}$ & Surgical Nursing & Prophylactic measures related to surgical wound infections. \\
\hline Nur/GO2 & $\begin{array}{l}\text { 5th } \\
\text { semester }\end{array}$ & $\begin{array}{l}\text { Semiology and } \\
\text { Semiotechnics II }\end{array}$ & Dressings: techniques and coverage. New therapeutic technologies. \\
\hline Nur/GO3 & $\begin{array}{l}\text { 5th } \\
\text { semester }\end{array}$ & $\begin{array}{l}\text { Semiology and } \\
\text { Semiotechnics II }\end{array}$ & Dressings: covering techniques. \\
\hline Nur/MT2 & $\begin{array}{l}\text { 4th } \\
\text { semester }\end{array}$ & Care Process I & $\begin{array}{l}\text { Emphasis on basic human needs for Oxygenation, Circulation, Thermoregulation, } \\
\text { Hygiene, Comfort and Skin Integrity. }\end{array}$ \\
\hline Nur/MT3 & $\begin{array}{l}\text { 4th } \\
\text { semester }\end{array}$ & Care Process I & $\begin{array}{l}\text { Emphasis on basic human needs for Oxygenation, Circulation, Thermoregulation, } \\
\text { Hygiene, Comfort and Skin Integrity. }\end{array}$ \\
\hline Nur/MT4 & $\begin{array}{l}\text { 4th } \\
\text { semester }\end{array}$ & Care Process I & $\begin{array}{l}\text { Emphasis on basic human needs for Oxygenation, Circulation, Thermoregulation, } \\
\text { Hygiene, Comfort and Skin Integrity. }\end{array}$ \\
\hline Nur/MS1 & $\begin{array}{l}\text { 3rd and 4th } \\
\text { semester }\end{array}$ & $\begin{array}{l}\text { Nursing } \\
\text { Fundamentals }\end{array}$ & Wound care. \\
\hline Nur/MS3 & $\begin{array}{l}\text { 3rd } \\
\text { semester }\end{array}$ & $\begin{array}{l}\text { Nursing } \\
\text { Fundamentals I }\end{array}$ & $\begin{array}{l}\text { Nursing care in the face of basic human needs related to hygiene, comfort and } \\
\text { oxygenation; communication and nursing records; maintenance of regulatory } \\
\text { functions; patient positioning; scientific nursing terminology; maintenance of } \\
\text { bodily integrity and wound care. }\end{array}$ \\
\hline Nur/MS4 & $\begin{array}{l}\text { 3rd } \\
\text { semester }\end{array}$ & $\begin{array}{l}\text { Nursing } \\
\text { Fundamentals I }\end{array}$ & $\begin{array}{l}\text { Nursing care in the face of basic human needs related to hygiene and comfort, } \\
\text { maintenance of bodily integrity and wound care. }\end{array}$ \\
\hline
\end{tabular}

PIHE= Public Institution of Higher Education; Nur= Nursing; DF= Distrito Federal; GO= Goiás; MT= Mato Grosso; MS= Mato Grosso do Sul. 


\section{Bibliography for teaching topics related to stomatherapy}

Eight bibliographical references were identified and distributed in the syllabuses of seven PIHE (Table 2). Of these, only one was observed to have an association between discipline, description of the topic/content and bibliography with an approach to a topic related to stomatherapy.

Regarding the characteristics of the references, the use of books focusing on general wound care $(n=07)$ and 1 specific for the care of pressure injuries was unanimous. Mandatory references on ostomies or incontinences were not identified. The year of publication of the books ranged between 2007 and 2014, all of them nationally produced.

Table 2. Distribution of data from public higher education institutions according to semester, subject and mandatory and complementary bibliographic reference. Brasília (DF) - 2020.

\begin{tabular}{|c|c|c|c|}
\hline PIHE & Semester(s) & Discipline(s) & Bibliographic reference - mandatory \\
\hline $\begin{array}{l}\text { Nur/DF2 } \\
\text { Nur/GO4 } \\
\text { Nur/MS2 }\end{array}$ & $\begin{array}{l}\text { 4th semester } \\
4 \text { th semester } \\
7 \text { th semester }\end{array}$ & $\begin{array}{l}\text { Nursing Fundamentals } \\
\text { Basis for the Care of the Individual and the } \\
\text { Family II. } \\
\text { Adult and Elderly. } \\
\text { Dimensions of Nursing Care IV. }\end{array}$ & $\begin{array}{l}\text { Borges EL, et al. Feridas: Como Tratar. } 1^{\circ} \text { ed. Belo } \\
\text { Horizonte: Coopmed; } 2007.248 \text { p } \\
\text { Dealey C. Cuidando de feridas: um guia para as } \\
\text { enfermeiras. } 3^{\text {a }} \text { ed. São Paulo: Atheneu Editora; } \\
\text { 2008. 248p. }\end{array}$ \\
\hline Nur/DF2 & 6th semester & Integrating Experiences 5 & $\begin{array}{l}\text { Blanes L, Ferreira LM. Prevenção e tratamento de } \\
\text { úlcera por pressão. São Paulo: Atheneu; } 2014 .\end{array}$ \\
\hline $\begin{array}{l}\text { Nur/DF2 } \\
\text { Nur/MS1 }\end{array}$ & $\begin{array}{l}\text { 6th semester } \\
3 \text { rd,4th,5th } \\
\text { and 6th } \\
\text { semesters }\end{array}$ & $\begin{array}{l}\text { Nursing Fundamentals II } \\
\text { Adult and Elderly Health Nursing I }\end{array}$ & $\begin{array}{l}\text { Jorge AS, Dantas SRPE. Abordagem } \\
\text { multiprofissional de ferida. Campinas: Atheneu, } \\
2003 .\end{array}$ \\
\hline Nur/GO4 & 4th semester & $\begin{array}{l}\text { Basis for the Care of the Individual and the } \\
\text { Family II }\end{array}$ & 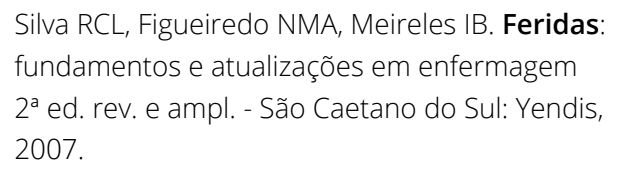 \\
\hline Nur/MT1 & $\begin{array}{l}\text { 4th } \\
\text { semester }\end{array}$ & The care process: foundation and practice. & $\begin{array}{l}\text { Irion GL. Feridas: novas abordagens, manejo } \\
\text { clinico e atlas em cores. 2aed. Rio de Janeiro: } \\
\text { Guanabara Koogan, } 2005 .\end{array}$ \\
\hline Nur/MT4 & $\begin{array}{l}4 \text { th semester } \\
9 \text { th and } 10 \text { th } \\
\text { semester }\end{array}$ & $\begin{array}{l}\text { Care Process I. } \\
\text { Supervised internship I e II }\end{array}$ & $\begin{array}{l}\text { Blanck M, Giannini T. Úlceras e feridas - As } \\
\text { feridas têm alma. Di livros, } 2014 . \\
\text { Geovanini T. Tratado de Feridas e Curativos: } \\
\text { Enfoque Multiprofissional. Bahia: Rideel, } 2013 . \\
\text { Malagutti W. Feridas: conceitos e atualidades. } \\
\text { 1ª ed. Martinari: } 2015 .\end{array}$ \\
\hline Nur/DF3 & $\begin{array}{l}\text { 7th and 8th } \\
\text { semesters }\end{array}$ & $\begin{array}{l}\text { Mandatory Curricular Internship in Hospital Care } \\
\text { (Women's Health/Newborn, Child/Adolescent, } \\
\text { Adult/Elderly) }\end{array}$ & $\begin{array}{l}\text { Blanes L, Ferreira LM. Prevenção e tratamento de } \\
\text { úlcera por pressão. São Paulo: Atheneu; } 2014 .\end{array}$ \\
\hline
\end{tabular}

PIHE= Public Institution of Higher Education; Nur= Nursing; DF= Distrito Federal; GO= Goiás; MT= Mato Grosso; MS= Mato Grosso do Sul.

\section{Category 2: Approach to themes related to stomatherapy in elective subjects}

Among the PIHE, two offered optional subjects focused on the care and treatment of wounds, two on nursing care in stomatherapy, one on the care of "people with a stoma" and one included the prevention of pressure injuries as a topic of risk management and safety of the patient (Table 3). 
Table 3. Distribution of data from public higher education institutions according to discipline and syllabus.Brasília (DF) - 2020.

\begin{tabular}{|c|c|c|}
\hline PIHE & Discipline & Syllabus \\
\hline Nur/DF2 & $\begin{array}{l}\text { Nursing Care in Acute and Chronic } \\
\text { Wounds }\end{array}$ & $\begin{array}{l}\text { Theoretical-practical discipline that develops the conceptual bases of } \\
\text { nursing care for clients with chronic and acute wounds, with a focus on } \\
\text { the prevention and treatment of wounds. }\end{array}$ \\
\hline Nur/GO1 & $\begin{array}{l}\text { Patient safety in the hospital } \\
\text { environment }\end{array}$ & $\begin{array}{l}\text { Patient safety in accordance with current legislation: fall prevention } \\
\text { protocols, prescription safety, patient identification, hand hygiene practice, } \\
\text { safe surgery and pressure injuries prevention. }\end{array}$ \\
\hline Nur/GO2 & Nursing in Stomal Therapy & $\begin{array}{l}\text { Stomata, anal, urinary incontinence and wounds. Specific care and } \\
\text { materials used in assistance. Science of technical knowledge and principles } \\
\text { of the relationship of help and autonomy. }\end{array}$ \\
\hline Nur/GO3 & Assistance in Stomal Therapy & Not available \\
\hline Nur/MT5 & Nursing Care for Ostomized People & $\begin{array}{l}\text { To present equipment and adjuvants used in the care of intestinal } \\
\text { stomas, in addition to discussing the nutritional, psychosocial and sexual } \\
\text { aspects of patients undergoing intestinal stomas. Discuss aspects of } \\
\text { rehabilitation of patients with intestinal stoma, inclusion policies and } \\
\text { human rights. }\end{array}$ \\
\hline Nur/MT5 & Nursing Care for Patients with Wounds & $\begin{array}{l}\text { Skin anatomy and physiology - evolution of healing - factors that } \\
\text { interfere with wound care - general principles for wound care - etiology } \\
\text { of major ulcers - wound cleaning and debridement - myths and truths } \\
\text { - coverages and new approaches and alternatives for the wound care - } \\
\text { wound care protocols. }\end{array}$ \\
\hline
\end{tabular}

PIHE= Public Institution of Higher Education; Nur= Nursing; DF= Distrito Federal; GO= Goiás; MT= Mato Grosso; MS= Mato Grosso do Sul.

Among the PIHE that offered elective courses, only two mentioned mandatory basic and complementary references (Table 4).

Table 4. Distribution of data from public higher education institutions according to the basic and complementary bibliographic reference for optional subjects. Brasília (DF) - 2020.

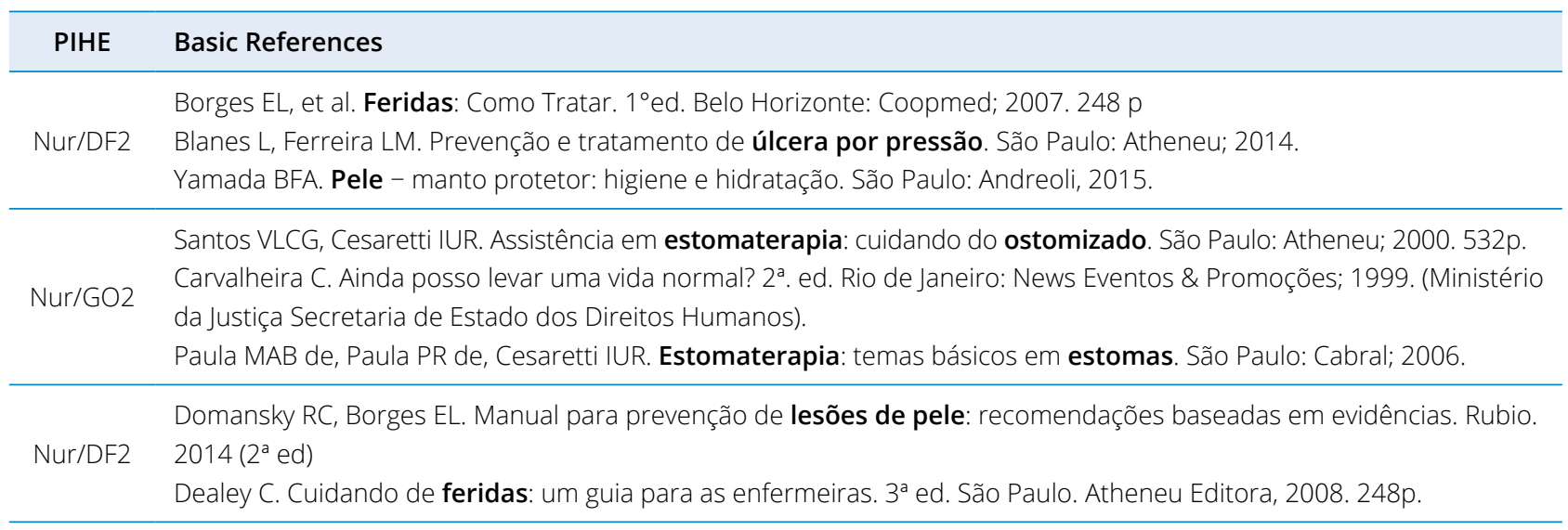

PIHE=Public Institution of Higher Education; Nur= Nursing; DF= Distrito Federal; GO= Goiás.

\section{Category 3: Approach to themes related to stomatherapy in extension activities}

In four web pages of the consulted nursing courses, extension activities (extension projects, academic league and community service) linked to stomatherapy were noted, but in only two the description of the activities was available (Table 5). The central theme of work is the assessment and treatment of wounds (acute and chronic) and pediatric urology. 
Table 5. Distribution of data from public higher education institutions according to the type of extension activity. Brasília (DF) - 2020.

\begin{tabular}{|c|c|c|}
\hline PIHE & Type of extension activity & Description of extension activities \\
\hline Nur/DF1 & Academic League of Nursing Wounds & $\begin{array}{l}\text { The Academic League of Wounds in Nursing intends to bring together } \\
\text { students from the Nursing course of the same unit, aiming to integrate } \\
\text { them into the scenarios of professional practice. Its principles are } \\
\text { knowledge, education and assistance, like the numerous academic leagues } \\
\text { created in other universities in Brazil and around the world. }\end{array}$ \\
\hline \multirow{2}{*}{ Nur/DF2 } & $\begin{array}{l}\text { Project: Advanced Nursing } \\
\text { Practice in Uropediatrics }\end{array}$ & Not available \\
\hline & $\begin{array}{l}\text { Outpatient Stomatherapy } \\
\text { Nursing Service }\end{array}$ & Not available \\
\hline Nur/GO3 & $\begin{array}{l}\text { Project: Prevention of pressure injuries } \\
\text { in the elderly in the city of Itumbiara-GO }\end{array}$ & Not available \\
\hline Nur/ MT5 & $\begin{array}{l}\text { Project: Study Group on } \\
\text { Chronic Wounds }\end{array}$ & $\begin{array}{l}\text { Objective: to provide opportunities for study, discussion and practice } \\
\text { on the assessment and treatment of chronic wounds among nursing } \\
\text { students and professors as a way to improve the participants' knowledge } \\
\text { about nursing care in the treatment of wounds (...). }\end{array}$ \\
\hline
\end{tabular}

PIHE= Public Institution of Higher Education; Nur= Nursing; DF= Distrito Federal; GO= Goiás; MT= Mato Grosso.

\section{DISCUSSION}

This documentary research made it possible to explore, among the PIHE in the Brazilian Midwest, how the themes related to stomatherapy are addressed in the PP and syllabuses of the disciplines of the undergraduate nursing courses. These are present in mandatory disciplines, optional or extension actions proposed in the courses.

It should be emphasized that nursing education provides for the training of critical and reflective professionals, able to work in health and care for individuals, families and communities in their different life cycles, according to their health needs ${ }^{1}$. Assisting patients with health demands included in the field of stomatherapy is a competence to be developed during graduation, given the need for qualified assistance to chronic patients, a group with a higher prevalence of skin lesions, stomas, incontinences, or those who use of catheters or drains 5 .

Regarding compulsory subjects, the results obtained are similar to a study carried out in Rio de Janeiro at an PIHE. The themes related to stomatherapy were predominantly related to wounds, whose teaching starts from the third semester of the course and extends to the last semester with contents about the healing process, classification and the main types of dressings used in the prevention and treatment of injuries.

Assisting patients with wounds is part of the nursing care process, with this professional being responsible for evaluating, prescribing and executing dressings, as well as supervising the nursing staff ${ }^{8}$. It is essential, therefore, that in the academic space, subsidies for the construction of such competences are offered to guarantee safe care.

In undergraduate nursing, the use of innovative and emancipatory methodologies in teaching topics in the field of stomatherapy is increasing. These have the potential to reinforce cognitive skills, allow skill training and experience situations similar to those they will encounter in clinical practice. High-fidelity clinical simulation, performed with simulated patients, role play and moulage, favor clinical reasoning and decision-making in the assessment and treatment of wounds ${ }^{9,10}$. Educational games and the use of gamification principles are also reported as applicable strategies for teaching contents related to ostomies and dressings ${ }^{11,12}$.

With the data compiled in this research, it is inferred that the initial years of the nursing course are the basis for knowledge and learning of the minimum skills for wound care, which are retrieved in subsequent years through theoretical support in bibliographic references basic and/or complementary. 
In compulsory subjects, the themes ostomy, incontinence, catheters and drains were not identified, or appeared less frequently. This data is corroborated by an analogous study, which signals the need to introduce the subject already at graduation, given the prevalence of incontinence problems, especially in the elderly, women, children, and the psychophysiological suffering of those affected by such a problem, which directly influences the quality of life 5 .

With regard to bibliographical references, among those identified, two are specific about pressure injuries (PI). This content is relevant for professional training, given that in 2013 the National Plan for Patient Safety (Plano Nacional de Segurança do Paciente-PNSP) was instituted by the Ministry of Health, and with it, the international patient safety goals were disclosed, one of them directed to the prevention of PI in health services.

According to the national report of incidents related to health care, from June 2019 to May 2020, of the 151,442 reported incidents, 29,416 (19.42\%) corresponded to PI, being, in this period, the second type of adverse event most notified by the country's health services ${ }^{13}$. Thus, due to the need to prevent, identify and treat PL, the inclusion of this theme in nursing education is emerging.

In the analyzed PIHE, books are the primary source for content theorization. This fact is associated with the library collection of institutions, which, for the most part, have basic and traditional literature for professional training. The books identified in the survey are exclusively national productions from the last 10 years.

It is considered that it is necessary to search for updated references and that it is up to the professor and educational institution to encourage and provide students with access to periodicals and publications on the news in the field of stomatherapy. In this aspect, the relevance of the dissemination of evidence-based practice and the curricular insertion of this proposal is projected so that it permeates the entire process of professional training ${ }^{14}$. It is suggested that clinical protocols, randomized clinical trials and systematic literature reviews be included in the references.

Among the results provided by the research is the detection of obsolete terminology such as pressure ulcers and ostomies. In 2016, the National Pressure Ulcer Advisory Panel (NPUAP), an organization dedicated to the prevention and treatment of PI, announced the change of the term "pressure ulcer" to "pressure injury", as it more accurately describes lesions in intact skin. and ulcerated ${ }^{15}$. Since 2004 the term "ostomia" was changed to "estomia", after Sociedade Brasileira de Estomaterapia (Brazilian Society of Stomatherapy) consulted with the Academia de Brasileira de Letras ${ }^{16}$.

With regard to elective subjects, the offer was identified for six PIHE distributed among the States of Goiás, Mato Grosso and the Distrito Federal. These disciplines configure alternatives to promote a better understanding of the themes: assessment, prevention and treatment of wounds (acute and chronic), care for patients with ostomy, urinary and anal incontinence and prevention of PI adverse events.

This modality of disciplines makes up the curriculum, but the academic is autonomous to choose whether or not to take it. In general, elective courses aim to provide more personalized training in a given theme or subject ${ }^{1}$. With the growing number of patients with skin lesions, ostomies and urinary or anal incontinence, in addition to the emergence of equipment and technologies to treat these health problems ${ }^{17}$, the inclusion of disciplines that allow academics to expand their competences in undergraduate nursing curricula is defended, preparing them for the care of these patients.

This statement is reiterated by noticing in the literature studies that indicate weaknesses in the knowledge of nursing students in the contents of wounds ${ }^{18}$ and $\mathrm{PI}^{19}$. Incontinences were mentioned in only one discipline that is included in the list of electives. A study that identified low knowledge of the subject "urinary incontinence" among nursing students, alerts to the need to review learning programs with a view to expanding their approach ${ }^{20}$. In relation to ostomies, creating opportunities for the student to train skills for emptying and selecting devices and changing the colostomy bag can increase confidence for this type of care ${ }^{21}$.

Support for nursing education also involves involvement with extension activities. The research findings indicated five outreach activities aimed at caring for patients with chronic and acute wounds and incontinence. Of these, three are concentrated in the Distrito Federal: an Academic League and two extension projects.

Extension activities should be an integral part of the undergraduate curriculum of higher education institutions. These provide for the dialogic interaction between the academic environment and the community, in order to promote the exchange of knowledge and interdisciplinary and interprofessional work. More recently, this debate has expanded in 
the face of the extension of the curriculum in which extension actions are expected to be included in at least $10 \%$ of the student curricular workload ${ }^{22}$.

In this sense, the link between academia and community is referenced in the descriptions compiled in two outreach activities. Offering services beyond the walls of the University is a commitment of PIHE. In this process, in addition to providing nurses in training with learning about the specialty ${ }^{23}$, it collaborates with the health care network by providing one more point of assistance to the population.

An experience of the Academic League in Stomal Therapy in Brazil reports the improvement of participating academics in the face of wounds, ostomies and incontinence, the relevance of the experience gained in the extension and applicability of the contents studied for the performance of professional practice ${ }^{23}$.

As a limitation of the study, the absence of documents available online and a detailed description of the extension activities developed in the context of the analyzed nursing courses are pointed out. Furthermore, only public documents, available on the official page of the consulted undergraduate courses, were evaluated, and it is pertinent to observe learning programs, subject plans and the hidden curriculum.

In view of the above and with a view to intensifying the approach to stomatherapy contents during nursing graduation, it is suggested that institutions look carefully at the relevance of the themes for professional practice. It is also important to encourage academics to seek updates that support their clinical practice ${ }^{24}$ and prepare them to care for individuals with wounds, incontinences and ostomies.

\section{CONCLUSION}

By analyzing the PP and syllabuses of the undergraduate nursing courses of the PIHE in the Brazilian Midwest, it was possible to identify a predominance of the content of wounds and, to a lesser extent, ostomy and incontinence. The subject is approached from the third semester, in compulsory subjects, with a focus on knowledge and skills training, supported by bibliographic references from the last 10 years.

When it comes to ostomy and incontinence, it is concluded that the academic is given the opportunity to expand knowledge on these themes in optional subjects or extension activities. In this respect, they will participate in these academic activities that are interested in going deeper into these subjects, which does not exclude the need to offer them in subjects of the mandatory flow.

It is considered necessary that nursing graduates have minimal knowledge about the concept of ostomy, the different types, indications, complications, general nursing care and skills to refer patients in need of specialized care.

Regarding the incontinence theme, graduation has the role of socializing knowledge and raising reflections among undergraduates about the importance of professional nurses in caring for patients affected by different types of incontinence.

It is understood that the objective of institutions is generalist training, but the need to apprehend knowledge and develop specific skills that are required in professional practice is notorious.

This research aims to add value to higher education in nursing, offering to PIHE and other institutions subsidies for reflection and curriculum evaluation in the dissemination of topics related to stomatherapy in higher education in nursing.

To deepen investigations on the teaching of stomatherapy, it is suggested that more comprehensive studies that include learning programs, teaching plans and the hidden curriculum, so that it is possible to obtain an overview of the teaching of topics related to stomatherapy in nurse training nationwide.

\section{AUTHORS' CONTRIBUTION}

Conceptualization: Morais FPF and Cauduro FLF; Methodology: Morais FPF and Cauduro FLF; Research: Morals FPF; Writing - First version: Morais FPF, Santos PHF and Cauduro FLF; Writing - Reviewing \& Editing: Morais FPF, Santos PHF and Cauduro FLF; Supervision: Cauduro FLF. 


\section{DATA AVAILABILITY STATEMENT}

Data sharing is not applicable

\section{FUNDING}

Not applicable

\section{ACKNOWLEDGEMENT}

Not applicable

\section{REFERENCES}

1. Ministério da Saúde (BR). Resolução do Conselho Nacional da Saúde n. 573, de 31 de janeiro de 2018. Recomendações do Conselho Nacional de Saúde à proposta de Diretrizes Curriculares Nacionais do curso de graduação Bacharelado em Enfermagem. Diário Oficial da União [periódico na internet], Brasília (DF). 06 nov 2018 [cited 10 sep 2021]. Available at: https:// www.in.gov.br/materia/-/asset_publisher/Kujrw0TZC2Mb/content/id/48743098/do1-2018-11-06-resolucao-n-573-de-31-dejaneiro-de-2018-48742847

2. Santos VLCG, Cesaretti IUR. Assistência em Estomaterapia: Cuidando de Pessoas com Estomia. $2^{\circ}$ ed. São Paulo: Atheneu; 2015.

3. World Council of Enterostomal Therapists (WCET). Mission, Values \& Vision [Internet]. [Acesso em 10 set 2021 ]. Available at: www.wcetn.org

4. Gontijo TG, Borges EL, Ferraz AF, Pires Júnior JF, Spira JAO. Atuação profissional dos estomaterapeutas egressos da Universidade Federal de Minas Gerais. ESTIMA Braz J Enterostomal Ther. 2019;17:e1419. https://doi.org/10.30886/estima.v17.686_PT

5. Gonçalves FGA, Reis FLM, Silva NAB, Souza NVDO, Varella TCMML, Pires AS. Conteúdo de estomaterapia e estratégias de ensino no currículo de graduação em enfermagem. Rev. Enferm UERJ. 2018;26:e28921. http://doi.org/10.12957/reuerj.2018.28921

6. Rodrigues RA, Bueno AA, Silva LM, Kusumota L, Almeida VC, Giacomini SB et al. O ensino de enfermagem gerontológica nas instituições públicas brasileiras de ensino superior. Acta Paul Enferm. 2018;31(3):313-20. https://doi.org/10.1590/19820194201800044

7. Oliveira DC. Análise de conteúdo temático-categorial: uma proposta de sistematização. Rev. enferm. UERJ. 2008; [acesso em 10 set 2021];16(4):569-76. Available at: https://pesquisa.bvsalud.org/portal/resource/pt/bde-16162

8. Conselho Federal de Enfermagem, Brasília. Resolução Cofen n. 0567/2018. Regulamento da atuação da equipe de enfermagem no cuidado aos pacientes com feridas. Available at: http://www.cofen.gov.br/wp-content/uploads/2018/02/ ANEXO-RESOLU\%C3\%87\%C3\%830-567-2018.pdf

9. Silva JLG, Oliveira-Kumakura ARS. Clinical simulation to teach nursing care for wounded patients. Rev Bras Enferm. 2018;71(Suppl 4):1785-90. http://doi.org/10.1590/0034-7167-2017-0170

10. Alves NP, Gomes TG, Lopes MMCO, Gubert FA, Lima MA, Beserra EP et al. Simulação realística e seus atributos para a formação do enfermeiro. Rev enferm UFPE online. 2019; [acesso em 09 set 2021];13(5):1420-8. Available at: https://periodicos.ufpe.br/ revistas/revistaenfermagem/article/view/239014/32337

11. Silva KCS, Barros MBSC, Silva VAO, Sanches LMP, Neto JAM, Alves SJO. Gamificação como Tecnologia Educacional Auxiliadora no Ensino de Curativos. In: Congresso sobre tecnologias na educação. 2019;504-10. https://doi.org/10.5753/ctrle.2019.8923

12. Marques BLC, Chave USB, Costa CCP. Relato de experiência sobre a criação de um jogo educativo acerca dos conteúdos de estomaterapia para estudantes do curso de enfermagem. Revista Presença. 2019; [acesso em 10 set 2021];1(13). Available at: http://sistema.celsolisboa.edu.br/ojs/index.php/numerohum/article/view/198/144

13. Agência Nacional de Vigilância Sanitária (BR). Núcleos de Segurança do Paciente. Relatórios Eventos Adversos dos Estados. Incidentes relacionados à assistência à saúde. Resultados das notificações realizadas no Notivisa - Brasil, junho de 2019 a maio de 2020 [acesso em 10 set 2021]. Available at: https://www20.anvisa.gov.br/segurancadopaciente/index.php/publicacoes/ category/relatorios-dos-estados

14. Moreno-Monsiváis MG. Practice Based on Scientific Evidence as the Foundation of Clinical Practice. Aquichan. $2019 ; 19$ (3):e1931. https://doi.org/10.5294/aqui.2019.19.3.1 
15. Caliri MHL, Santos VLCG, Mandelbaum MHS, Costa MSN IG. Classificação das lesões por pressão - Consenso NPUAP 2016 Adaptada culturalmente para o Brasil. [internet] Associação Brasileira de Estomaterapia SOBEST e Associação Brasileira de Enfermagem em Dermatologia- SOBENDE [acesso em 10 set 2021]. Available at: http://www.sobest.org.br/textod/35

16. Yamada B. Associação Brasileira de Estomaterapia: estomias, feridas e incontinências - SOBEST [Internet]. Fundação. 2016 [acesso em 10 set 2021]. Available at: http://www.sobest.org.br/texto/3

17. Souza NVDO, David HMSL, Mauricio VC, Costa CCP. Enfermagem em Estomaterapia no telessaúde UERJ: Relato de Experiência. J Bras Tele. 2014;3(2):70-2. https://doi.org/10.12957/jbrastele.2014.13593

18. Baratieri T, Sangaleti CT, Trincaus MR. Conhecimento de acadêmicos de enfermagem sobre avaliação e tratamento de feridas. Rev Enferm Atenção Saúde. 2015; [acesso em 10 set 2021];4(1):2-15. Available at: http://seer.uftm.edu.br/revistaeletronica/ index.php/enfer/article/view/1259

19. Furtado AF, Marcondes L, Lenhani BE, Batista J. Conhecimento de acadêmicos de enfermagem sobre lesões por pressão: desafio para a segurança do paciente. Rev baiana enferm. 2019;33:e34425. https://doi.org/10.18471/rbe.v33.34425

20. Luo Y, Parry M, Huang YJ, Wang XH, He GP. Nursing students' Knowledge and atitudes toward urinary incontinence: A cross sectional survey. Nurse Educ Today. 2016;40:134-9. https://doi.org/10.1016/j.nedt.2016.02.020

21. Zimnicki K, Pieper B. Assessment of prelicensure undergraduate baccalaureate nursing students: ostomy knowledge, skill experiences, and confidence in care. Ostomy Wound Manage. 2018;64(8):35-42. https://doi.org/10.25270/owm.2018.8.3542

22. Ministério da Educação (BR). Resolução n. 7 Conselho Nacional de Educação, de 18 de dezembro de 2018. Estabelece as Diretrizes para a Extensão na Educação Superior Brasileira. Diário Oficial da União [periódico na internet], Brasília (DF). 19 dez 2018 [cited 10 sep 2021]. Available at: http://portal.mec.gov.br/index.php?option=com_docman\&view=download\&ali as=104251-rces007-18\&category_slug=dezembro-2018-pdf\&ltemid=30192

23. Carvalho NAR, Nolêto IRSG, Santos JDMS, Benício CDAV, Bezerra SMG, Luz MHBA. Vivências de acadêmicos de enfermagem em uma liga de estomaterapia. Rev Enferm UFPI. 2015;4(4):105-8. https://doi.org/10.26694/reufpi.v4i4.3045

24. Prado ARA, Barreto VPM, Tonini T, Silva AS, Machado WCA. O saber do enfermeiro na indicação de coberturas no cuidado ao cliente com feridas. ESTIMA Braz J Enterostomal Ther. 2016;14(4):175-82. https://doi.org/10.5327/Z1806-3144201600040004 